\title{
The role of personal experiences in Norwegian perceptions of climate change
}

Päivi Lujala, Geography Research Unit, PL 8000, FI-90014 University of Oulu, Finland \& Department of Geography, Norwegian University of Science and Technology (NTNU), NO7491 Trondheim, Norway. Email: Paivi.Lujala@oulu.fi

Haakon Lein, Department of Geography, Norwegian University of Science and Technology (NTNU), NO-7491 Trondheim, Norway. Email: Haakon.Lein@ntnu.no

\begin{abstract}
It is commonly assumed that personal experiences of a changing climate will influence people's attitudes to the extent that they will be more likely to acknowledge anthropogenic climate change as a real threat and therefore be more willing to accept both mitigation and adaptation efforts. In this article, the authors examine how personal experiences with extreme events and climate-related changes in the natural environment influence attitudes to climate change. Using data from a nationally representative survey conducted in Norway in 2015 and logistic regressions, the authors find that personal observations of changes in nature are linked to higher levels of concern with regard to climate change as well as to attitudes that are more positive towards personal mitigation and adaption efforts. Somewhat counter-intuitively, they also find that those who had personally experienced a natural hazard event were less concerned for climate change. These results suggest that personal experience of the consequences of climate change can in some cases have a limited effect on enhancing people's concerns about climate change.
\end{abstract}

\section{Keywords}

climate change, perception, natural hazard, personal experience, change in the natural environment

\section{Acknowledgements}

We are grateful to the editor and reviewers for their excellent comments and suggestions. We also thank Gunhild Setten, Catriona Turner and the participants of the Geography Research Seminar at the Norwegian University of Technology and Science (NTNU) and the 8th Conference of the International Society for Integrated Disaster Risk Management (IDRiM) for discussions and feedback on earlier versions of this article. Author (2019) provides replication data and replication do-file that can be used to reproduce the estimations included in the tables and appendices.

\section{Funding}

This work was supported by the Research Council of Norway (grant number: RCN 235490) 


\section{Introduction}

Climate change is for many an abstract phenomenon that primarily will have an effect in a somewhat distant future, affects places far away, and mainly has an effect on 'other' people and communities (Ryghaug et al. 2011; Spence et al. 2012). In order to overcome this 'physiological distance', it has been claimed that local experiences of climate change that are more direct may influence peoples' attitudes to climate change and their willingness to act (Clayton et al. 2015; McDonald et al. 2015). Two types of local framings of climate change have been discussed in the literature: experiences of extreme events and disasters, and observed or experienced changes of more subtle and slow onset changes such as changes in temperature, precipitation, or seasons. Both types of framings are examined in this article.

We use a nationally representative survey of 1045 participants, conducted in 2015, and multivariate logistic regressions, to examine to what extent Norwegians' attitudes to climate change are related to their personal experiences of extreme weather events and respondents' personal observations of climate-related changes in the natural environment. The article focuses on three different types of climate-related outcomes from the respondents' perspective: (1) their perception of climate change as a general challenge to Norwegian society and as a personal threat; (2) their likelihood of engaging in mitigation efforts; and (3) their adaptation to climate change. With regard to personal experiences of weather-related natural hazards, we examine the effect of both having personally experienced an event that caused damage and of knowing someone who has experienced such an event.

The aim of this article is to contribute to a growing field of research that explore the relationship between personal experiences and people's perceptions of climate change, and their willingness to engage in climate change mitigation and adaptation efforts. A better understanding of these relationships is vital for assessing, for example, the efficiency of framing climate change as a direct and personal threat, in order to secure public support for mitigation and adaptation efforts.

\section{Literature review}

As mentioned in the Introduction, personal experiences of extreme weather events, as well as personal experiences of more subtle and slow onset environmental changes such as abnormal temperature and precipitation or changes in the start or end of seasons, may reduce the 'psychological distance' of climate change and this in turn may influence peoples' attitudes towards climate change. A basic argument is that if climate change is framed as local phenomena that will affect people 'at home', they will be more likely to acknowledge climate change as a real threat and therefore also be more willing to accept both mitigation and adaptation efforts (Scannell \& Gifford, 2013; Wiest et al. 2015).

With regard to experiences of extreme events and disasters, studies have shown that direct experience of extreme events make people more concerned about climate change (Broomell et al. 2015; Demski et al. 2017; Zanocco et al. 2018). However, Boon (2016) found that prior disaster experiences had no impact upon perceptions of the risks of climate change. Similarly, Whitmarsh (2008) found that direct experience of floods had little effect on flood victims' views on climate change. Lujala et al. (2015) found that that direct personal experience of damage caused by weather-related events led people to be more concerned about future personal consequences of climate change, but not more concerned about climate change as a serious challenge for Norwegian society as whole. 
In addition to discussions on the effects of experience of hazardous events on perceptions of climate change, another topic raised in the literature is whether the more subtle changes in the natural environment influence people's perceptions of climate change (Hamilton et al. 2010). Such effects may include changes in temperature, precipitation, or the beginning or end of seasons. A number of studies have revealed an immediate local temperature effect, as attitudes towards climate change issues have been found to vary according to changes in the temperature within the same day or on the previous day to the one on which people were asked questions about climate change (Li et al. 2011; Hamilton \& Stampone 2013; Zaval et al. 2014). Zaval et al. (2014) explain this local warming effect as 'attribute substitution', whereby people simply use readily available information such as today's or yesterday's temperature when making judgements about climate change.

A number of studies of climate change perceptions that have focused on personal experiences of changes in natural environment have used observed data. Howe et al. (2013) found that public perceptions of temperature change corresponded with observed patterns and that people living in places with rising temperatures were more likely to believe in climate change. McCright et al. (2014) found that in the USA peoples' perceptions of winter temperature anomalies correlated with the measured temperatures, but that a warmer winter did not increase their likelihood of attributing this to climate change. Hamilton \& Keim (2009) found that people living in areas that in recent decades have experienced declining average winter temperatures were more concerned about climate change impacts than were people living in areas where such declining temperatures had not happened.

However, also severe cold can be attributed to climate change, Capstick \& Pidgeon (2014) found that a period of severe cold weather in the UK was conceptualized by many as 'unnatural' weather caused by climate change. Akerlof et al. (2013) found that about one-quarter of their respondents had personally experienced effects of climate change through changes in, for example, the seasons, weather, and snowfall. The personal experiences of changes in the natural environment, most which could be confirmed by climatic records, had heightened people's perceptions of the risks related to climate change.

A few studies have looked at how extreme events and perceived changes in the natural environment influences peoples' attitudes and efforts in terms of climate change mitigation and adaption. Broomell et al. (2015) and Demski et al. (2017) found that people who had experienced extreme events were more willing to engage in mitigation and adaptation practices. Ray et al. (2017) found that individuals who had experienced extreme weather activity were more likely to support general policies relating to climate change adaptation policies, but that their level of support was modest, inconsistent across specific adaptation policies, and diminished with time.

The relationships between climate change, experience of hazards and changes in the natural environment, and perceptions of climate change are summarized in Figure 1. These relations form the conceptual framework for the analysis carried out in the next section. As shown in Figure 1, personal experiences are 'filtered' and thus the impact of a personal experience is moderated by individual factors (Clayton et al. 2015).

A number of studies have found that the effect of local perceptions of climate change and its consequences are strongly meditated by intervening factors, primarily peoples' political leanings and prior beliefs in anthropogenic climate change (Goebbert et al. 2012; Hamilton \& Stampone 2013; McCright et al. 2014, Ogunbode 2019). Myers et al. (2013) found a positive relationship between perceived personal experiences of climate change and belief in climate 
change. The personal experiences interacted with prior beliefs about climate change in a way that personal experiences had the largest effect for those who initially had low prior engagement in climate change issues. Political attitude and prior belief in climate change may also affect to what degree people report local climatic change, as studies show that those with a prior belief in climate change are more likely to report observed changes than those who are sceptical (Howe \& Leiserowitz 2013; Myers et al. 2013). Furthermore, Howe (2019) argues that the general tendency to seek information that confirms one's pre-existing belief - motivated reasoning - is highly relevant when exploring climate change related perceptions and beliefs. Using data from a Norwegian sample, Howe found that prior beliefs about global climate change did have an effect on reported perceptions of changes in temperature and precipitation.

Quantitative studies have shown that a person's age, gender, level of education, income, and attitudes towards environmental issues, as well as their interest in politics and political and human values, are all important for mediating that person's views on climate change and for understanding how an individual's or household's willingness to adopt measures to mitigate and adapt to climate change vary (e.g. Leiserowitz 2005; Clayton et al. 2015; Aasen \& Vatn 2018; Krange et al. 2018; Poortinga et al. 2019). In the case of Norway, Aasen (2017), Krange et al. (2018), and Lujala et al. (2015) show that women, those who are concerned about nature, or have a higher level of education are more likely to be concerned about climate change while those voting for right-wing parties are less inclined to be concerned about climate change. The same studies also provide some evidence that members of the younger generations are more concerned about climate change and its consequences. These findings are in line with other national and cross-national studies of perceptions of climate change and its consequences in Western countries (Poortinga et al. 2019)

\section{FIGURE 1 ABOUT HERE}

\section{Data and methods}

The data used in the analysis were sourced from TNS Gallup's (now Kantar TNS) annual Climate Barometer survey, conducted in February 2015 (TNS Gallup 2015). The main objective of the Climate Barometer survey is to study people's attitudes towards a broad range of climate and energy-related issues such as climate and industry policy, electric cars, energy efficiency, and environment-friendly consumption. Our sample consists of 1045 respondents who are representative of the adult population of Norway. The responses were collected using computer-assisted web interviewing (CAWI). Table 1 presents the descriptive statistics for the variables used in the analysis and the corresponding questions in the survey. For all variables, except for those noted in the variable description below, 'I do not know' answers were coded as missing data.

\section{TABLE 1 ABOUT HERE}

\section{Dependent variables}

Our analysis focused on three aspects related to climate change: (1) respondents' attitudes towards the seriousness of the consequences of climate change for Norway and for themselves; (2) their views on and engagement in mitigation efforts; and (3) their inclination to have implemented a measure to protect their property against natural hazards. 
Climate change as a national and personal challenge. The respondents were asked to choose the three most important challenges that Norway is currently facing. The list of challenges included the following: the queues for health care, immigration and integration, school and education, climate change, poverty and injustice, unemployment, narcotics, economic growth, defense, terrorism, increasing violence and crime, financial crisis, and culture.

Of the 1045 respondents, $40 \%$ listed climate change as among the three most important challenges, and overall, climate change was ranked as the second largest challenge after immigration and integration. For the analysis, we coded a dummy variable (Challenge for Norway) that takes the value of 1 if the respondent listed climate change as one of the three major challenges facing Norway and the value of 0 if climate change was not listed among the three major challenges.

To measure the level of concern for personal consequences of climate change, each respondent was asked to rate, on a five-point Likert scale, to what degree they agreed with the statement 'I am worried about the consequences that climate change may have for myself and my family'. The variable (Personal consequences) was coded by using a scale from 1 to 5, for which the value of 1 was given for the lowest level of concern. Half of the respondents partially or fully agreed with the statement.

Attitudes towards climate change mitigation efforts and actual personal mitigation efforts. We have two variables with which to measure respondents' inclination towards personal mitigation efforts: the first measures attitudes and the second measures what the respondent had done in practice. The first variable, Attitudes towards mitigation, was based on the question in which the respondent was asked to estimate to what degree they agreed with the statement 'I am concerned about what I can do to reduce my own burden on the climate.' The variable was coded by using a scale from 1 to 5 , assigning the value of 1 for the lowest level of concern. Over $70 \%$ of the respondents agreed with the statement fully $(24 \%)$ or to some degree $(48 \%)$.

The second variable, Real mitigation effort, was based on the question in which the respondent was asked to identify what they had done to reduce their own impact on the climate. The respondent could select alternatives from a 10-point list and indicate other ways that they had reduced their impact on the climate. The question was only asked if the respondent had either agreed fully or to some degree with the above-mentioned statement (Attitudes towards mitigation). The most commonly mentioned efforts to reduce negative impacts on climate were: waste sorting (84\%), reduced personal consumption (43\%), reduced indoor temperature (43\%), and the purchase of eco-labelled products $(37 \%)$. Other common alternatives included the purchase of organic food (29\%), the use of more environmentally-friendly modes of daily transport (26\%), and reduced air travel (20\%). Only $8 \%, 3 \%$, and $4 \%$ respectively reported they had purchased an electric or hybrid car, $\mathrm{CO}_{2}$ quotas to compensate for own emissions, or renewable energy. Of those who answered the question, $4 \%$ had not engaged in any effort, while c. $80 \%$ reported they had engaged in between one and four of the listed types of efforts. The variable Real mitigation effort was constructed as an additive count variable that recorded the number of different measures taken by the respondent. In order to keep the respondents who were not asked the question, we assigned them a value of 0 ; this added 285 observations to the sample.

Willingness to adapt. We measured the respondents' willingness to adapt to changes in climate by looking at their responses to a question in which they were asked to indicate whether they 
had taken any measures to reduce the risks to their property resulting from future natural hazards (Willingness to adapt). Of those who responded to the question, 25\% indicated that they had taken such a measure. The variable was coded as dummy that took the value of 1 for a positive answer. As some of our respondents may have not owned property, or owned property over which they to a lesser degree could decide, we also run estimations using a sub-sample of respondents that were both homeowners and lived in a house or semi-detached or terraced house. ${ }^{1}$ In our data, $85 \%$ of the respondents owned their home and $71 \%$ of these lived in a house or semi-detached or terraced house.

\section{Independent variables: climate change experience}

We measured the respondents' experiences of consequences related to climate change, at two different levels: (1) direct personal experience, and (2) knowledge of someone with experience.

Direct personal experience. The respondents were asked whether they personally had experienced a weather-related event by indicating whether they had experienced damage due to landslides, drought, storms, extreme warm periods, forest fires, or flooding (flood or storm surge) in their home locality. In total, c. $35 \%$ of the respondents reported such experiences, the most frequent being storms (25\%), flooding (12\%), and extremely high temperatures (heat waves, 6\%). The variable Direct personal hazard experience was coded as a dummy, where the value of 1 was assigned for respondents who had experienced at least one hazard type.

Additionally, the respondents were asked whether they had observed changes in the natural environment in their own municipality. Of the 1045 respondents, 32\% replied positively and $52 \%$ negatively, while 169 respondents (16\% of the sample) answered 'Do not know'. In order to retain in the analysis those who responded 'do not know' and those who did not answer the question, our second dependent variable, Observed change in nature, codes these answers as if the respondent had answered 'no'. The variable Observed change in nature is used in the main analysis. In an alternative coding, those who did not have a definite answer were excluded from the analysis by coding a dummy variable that takes the value of 1 for those who answered 'yes' and 0 for those who answered 'no' (Observed change in nature, original). Finally, to take into account the possibility that respondents who answered 'I do not know' were unsure of what type of changes they were asked about or would have chosen the alternative 'perhaps' if it had been available, an intermediate coding was used, where those who answered 'no' was assigned the value of 0 , those who did not know the answer were assigned the value of 1 , and those who answered 'yes' were assigned the value of 2 (Observed change in nature, ordinal).

Experiences of others. In addition to be asked about direct personal experiences of damage due to weather-related events, the respondents were asked whether someone they knew had experienced such damage. About $50 \%$ of the respondents gave a positive response to the question. The variable Hazard experience by others was coded in similar way as the abovementioned variable $O w n$ direct experience.

\footnotetext{
${ }^{1} \mathrm{We}$ thank our reviewer for pointing out that not all respondents live in or own a property that may be protected from natural hazards. Of course, some of the renters or those who live in apartments may own other property while some homeowners' property may be in a stand that does not require any protective measures.
} 


\section{Control variables}

In the analysis, we controlled for individual characteristics and attitudes (the 'filter' in Figure 1). As the basic demographic controls, we included age (in years, Age), education level (a 4point scale ranging from completion of lower secondary school to completion of a master's degree, Education), and gender (dummy, coded as 1 for females, Gender). The respondents' political leaning was categorized as support for green, left-wing, centre, and right-wing parties according to how they voted in the parliamentary elections in $2013 .^{2}$ Those who voted for other parties (9), voted blank (11), did not vote (59), did not answer the question (5), or said they did not know the answer (38) were included as a separate category (Other). In the analysis, those who voted for right-wing parties (Right) were used as the reference category when all categories were included in the analysis simultaneously.

To control for personal attitudes towards environmental issues, we included in the analysis a variable that measures to what degree environmental concerns were important for each respondent's consumption choices. The variable, Consumption choices, was measured with a 3-point scale, for which 1 denotes that the producer's environmental profile did not have any influence on the respondent's purchasing decision and 3 that it had a large influence. Of those who answered the question (c.100 did not), 67\% stated that environmental profile had some influence on their purchasing decisions and $12 \%$ that it had a large influence. We also included a variable named 'Environmental organizations', which measured each respondent's familiarity with 10 environmental organizations. ${ }^{3}$ For each organization, the familiarity was measured on a 5-point scale ranging from 'not very familiar' (denoted with value of 1) to 'very familiar' (denoted with value of 5). We calculated the mean score across all 10 organizations for each respondent. In cases when information was missing for an organization, that organization was assigned a value of 0 . If the information was missing for all organizations, the variable for that respondent was set to missing (25 respondents).

We measured income level of the respondent by including the variable Income, which was based on the annual income bracket for the respondent. The brackets ranged from under NOK 200,000 (USD 25,000) to over NOK 1,000,000 (USD 125,000), with NOK 100,000 (USD $12,500)$ intervals. We assigned the value of 1 to the lowest income bracket and 9 for the highest. The information was missing for almost 100 respondents.

Our final control measure is each respondent's self-assessment of the extent to which their home locality is exposed to natural hazards (Exposure to hazard). This was reported on a 5point scale ranging from very small extent to very large extent. We assigned the value of 1 to the lowest exposure and 5 to the highest. Almost $70 \%$ of the respondents considered that their home was either very little exposed or little exposed, while a further $25 \%$ considered it exposed to some degree. In total, respectively $5 \%$ and $1 \%$ considered their home highly exposed or very much exposed.

\section{Methods}

We used logistic regressions when our dependent variable is binary and ordered logistic regressions when the dependent variable has a meaningful sequential order. The respondents'

${ }^{2}$ Left-wing parties: the Norwegian Labour Party, the Red Party, and the Socialist Left Party; centre parties: the Centre Party, the Liberal Party, and the Christian Democrats; right-wing parties: the Conservative Party and the Progress Party.

${ }^{3}$ These include both international organizations such as Greenpeace, Zero, and the WWF as well as Norwegian organizations such as Bellona, and Nature and Youth. 
answers were weighted by gender, age, geographic location, and education, calculated by the TNS Gallup (TNS Gallup 2015). We used first-order Taylor series linearization (TSL) to calculate robust standard errors and included county fixed effects in all model specifications to limit county-level unobserved heterogeneity due to factors that we are not able to include in the analysis (these can be related, but not limited, to geography, differences in culture, infrastructure, economic conditions, and local institutions). With a few exceptions, as noted above, 'I don't know' and missing answers were coded as missing. We used STATA 15.1 in all analyses. Author (20XX) provides replication data and replication do-file that can be used to reproduce estimations include in the tables and appendices.

\section{Results}

In the following, we analyse each of our three dependent variable categories - climate change as a national and personal challenge, attitudes towards and actual personal mitigation efforts, and willingness to adapt. The results for climate change as a major challenge for Norway and concern for personal consequences are presented in Table 2, the results for mitigation in Table 3 , and those for adaptation in Table 4. The models presented in the tables show the odds ratios for logistic or ordered logistic regressions: values larger than 1 indicate an increase in the respondents' likelihood of reporting a higher value for the dependent variable and values less than 1 indicate a decreased likelihood. The odds ratio is interpreted in terms of each unit change in the dependent variable. For example, the interpretation of the odds ratio for Gender in Model 3 in Table 2, is that the odds for a woman is 1.41 times larger than the odds for a male for reporting climate change as a major challenge. For ordered logistic regression, the odds ratio indicates the increase or decrease in the respondents' likelihood of reporting a one-category higher answer. For example, for Gender in Model 4 in Table 2, women were 1.80 times more likely to report 'Partially agree' instead of 'Neither agree nor disagree' than were males.

\section{Climate change as a national and personal challenge}

Models 1-3 in Table 2 show the results for our first dependent variable, Challenge for Norway, which denotes whether a respondent considered that climate change was among the three major challenges that Norway faces, and Models 4-6 show the results for the dependent variable Personal consequences, which measures the respondent's level of concern for personal consequences of climate change. Models 1 and 4 include the experience variables Observed change in nature, Direct personal hazard experience, and Hazard experience by others as well as the standard background control variables (age, gender, education level, and political leaning). Models 2 and 5 include further controls for environmental attitudes, income level, and exposure of own home. The inclusion of these controls reduce the sample size by over 160 observations. Therefore, to increase the sample size, we also present more parsimonious estimations (Models 3 and 6), in which we keep the core background variables (age, gender, and education), include a dummy variable for respondents who voted for right-wing parties, and keep the variable for environmental values for which we had the most observations, namely Environmental organizations.

\section{Table 2 ABOUT HERE}

The results relating to our dependent variables are interesting because they indicate considerable differences between the different types of experiences: Direct personal hazard 
experience has negative relation to level of concern (i.e. own experience of a natural hazard decreases the likelihood of a respondent reporting climate change as a major challenge for Norway or as a personal challenge), while those who reported having Observed change in nature are more likely to be concerned about climate change. Hazard experience by others has a positive sign in most estimations, but is not significant at the conventional level, except for Model 4, having a borderline level of significance in Model 6.

According to Model 3, the odds ratio for those who had Observed a change in nature to report climate change among the three largest challenges for Norway is 2.74 times larger than for those who had not observed such a change. For those with Direct personal hazard experience the odds ratio is 0.6 times as large as for those who do not have such an experience. The impact of the two variables on concern for personal consequences of climate change is similar: having observed a change in the natural environment substantially increases the respondents' likelihood of reporting a one category higher degree of concern, while their own direct experience reduces the likelihood (Model 6). A marginal effect analysis of Model 6 showed that, when keeping all other variables at their mean values, having observed a change in the natural environment increases the respondents' likelihood of reporting the highest level of concern for personal consequences from 12.2\% (when having not observed a change) to $29.0 \%$ (when having observed a change), while own direct experience of a hazard resulted in a decrease from $17.9 \%$ to $13.7 \%$, respectively 17 and 4 percentage point changes.

The control variables reveal the following tendencies. Older respondents tend to be more concerned (Age), but this relation disappears when we control for environmental attitudes. Women (Gender) are more concerned than men are, especially about the personal consequences of climate change. Those with higher education levels (Education) are more likely to list climate change among the major challenges Norway is facing, but interestingly, education level is not related to respondents' level of concern for personal consequences. There is a clear tendency that respondents who are politically inclined towards right-wing parties (Right) to be less worried about climate change and its consequences for Norway and for themselves compared to those who voted for other parties or abstained from voting.

Respondents with greater familiarity with Environmental organizations and those who take into account the environment in their Consumption choices are more likely to be worried about climate change. Those with higher incomes are more likely to be concerned about the personal consequences of climate change, but do not show any increased concern about climate change as a collective threat for Norway. Level of Exposure of the home location to hazards is not related to the aforementioned outcome variables.

As explained in the section 'Data and methods', the variable 'Observed change in nature' was recoded because a considerable proportion of the respondents did not have the opportunity to answer the question due to a screening question. As a robustness check, we ran estimations with the alternative variables Observed change in nature, original and Observed change in nature, ordinal. The results are reported in Appendix 1. These estimations showed that either excluding those who did not answer or answered 'I do not know' from the estimations (Models 1-6) or including them as an 'intermediate' category (Models 7-12) produce the same coefficient sizes and significance levels for the variables of interest as well as for the other included variables. I should be noted that in Models 7-12, the coefficient must be multiplied by itself in order to calculate the change from 'no' to 'yes' via the intermediate step 'perhaps' (e.g. for Model 7: $1.74 \times 1.74=3.03$ ). 


\section{Attitudes towards climate change mitigation and mitigation efforts}

Table 3 shows the main results for climate change mitigation. Models 1-3 focus on the respondents' attitude towards different types of personal mitigation efforts (Attitudes towards mitigation), and Models 4-6 focus on what efforts the respondents had actually engaged in (Real mitigation effort). Models 1 and 4 include the core background variables, Models 2 and 5 include additional control variables, and Models 3 and 6 present the more parsimonious estimations.

\section{TABLE 3 ABOUT HERE}

From the results it is clear that Direct personal hazard experience is not related to either of the outcome variables. Hazard experience by others consistently has a positive sign, but is not significant at conventional levels in any of the estimations. By contrast, Observed change in nature has a clear positive relation with the dependent variables: having seen a change in the natural environment increases the likelihood of a respondent being more concerned about how they could reduce their own impact on climate change, as well as the likelihood of them actually engaging in different types of mitigation efforts.

Women tend to be more positive towards climate change mitigation efforts and are more likely to have engaged in such efforts. Older respondents, although more likely to report a more positive attitude towards mitigation, do not seem to be more likely to engage in mitigation efforts. Education level do not affect attitudes towards mitigation, but do have a considerable impact on whether respondents actually engage in mitigation efforts: respondents with higher levels of education levels are more likely to have taken more mitigation measures. There also seems to be a tendency that those who voted for right-wing parties report lower rates of interest and engagement in personal mitigation efforts, while those who voted for the Green Party were the most positive towards personal mitigation efforts. Additionally, those with more environmentally-friendly attitudes have more positive attitudes towards climate change mitigation. Level of income and perception of the home location's exposure to weather-related events are not related to the outcome variables.

As the dependent variable in Models 4-6 can be considered to be a count variable (i.e. how many of the possible mitigation efforts the respondent had engaged in), we conducted a robustness analysis using negative binomial regression (see Appendix 2, Models 1-3). Further, 285 respondents were not asked the question on which the variable 'Real mitigation effort is based' (see the variable descriptions in the section 'Data and methods'). Models 4-6 in Appendix 2 provide estimations in which the 285 respondents were excluded from the analysis. In all estimations, our variables of interest were robust to the alternative estimation methods.

\section{Willingness to adapt}

Table 4 shows the results for the outcome variable Willingness to adapt, namely whether a respondent had implemented a measure to protect their home from future weather-related natural hazards. Models 1-3 report the results for the full sample while Models 4-6 show the results for the sub-sample that are homeowners and live in a house or semi-detached or terraced house. Models 1, 2, 4 and 5 include the control variables as in Tables 1-3, and in Models 3 and 6 the variables Consumption choices and Income are excluded in order to increase the sample size.

\section{TABLE 4 ABOUT HERE}


The results show that Direct personal hazard experience is strongly related to the likelihood of a respondent having implemented a measure to protect their own property: the odds are 2.4 times as large as for those who did not have such experience (Model 3) and 3.3 times larger in the sub-sample (Model 6). Observed change in nature is positively correlated with the likelihood of a respondent having implemented a protective measure, although the result is not significant in all estimations. Additionally, Hazard experience by others has a positive sign but fails to be significant at the conventional levels.

Older respondents, respondents with higher incomes, and respondents who are living in more exposed locations are more likely to have implemented measures to protect their homes from natural hazards. There does not seem to be any relation between gender, education level, and political leaning and respondents who had implemented protection measures, but the results suggest that willingness to adapt may be positively related to environmental attitudes (Model 2 and 5, Consumption choices). In general, Models 4-6 report weaker results, which is not surprising considering that the sample size is reduced by over $45 \%$ compared to the full sample.

\section{Discussion}

The most remarkable results from the analysis were the relation between Direct personal hazard experience and perception of climate change as both a collective challenge and personal challenge. As discussed in the literature review, it is commonly assumed that direct experience of climate-related damage may help to shorten the 'psychological distance' of climate change, in turn making people more concerned about climate change 'at home' and its consequences. However, in our study, we found that those with direct personal experience of weather-related hazardous events actually perceived climate change as less of a threat compared with those who had not had such experiences. This finding is somewhat similar to Whitmarsh's finding that flood victims were not particularly concerned with climate change because they regarded floods and climate change as two rather separate issues (Whitmarsh 2008). Flood were primarily perceived to have local and immediate causes (such as blocked ditches and drains), which are issues that can be solved locally without being concerned about climate change.

A somewhat different possible explanation for the apparent paradox that became apparent following our analysis is that respondents who had experienced climate-related damage also had experienced that it was quite manageable. Several context-specific reasons may contribute to this. In Norway, natural hazards rarely result in casualties and damage is largely confined to loss of property. Generally, damage to houses is covered by insurance, as all who have fire insurance are compelled to pay a premium for damage caused by storm, flooding, landslides, earthquakes, and volcanic eruptions. ${ }^{4}$ The rate for this insurance is $0.007 \%$ of the amount of insurance against fire damage and is the same for all insurance companies and insured persons, regardless of their place of residence. In addition, Norway has a well-functioning welfare state, with good emergency services and a public sector that is capable of taking care of those who are injured or evacuated from their homes for shorter and longer periods. Further, as shown by the results of our analysis, those who had experienced an event that had caused damage were more likely to have taken measures to protect their homes from future events. Thus, the respondents might have assumed that if they were hit by an event again, they would probably be sufficiently robust to withstand it.

\footnotetext{
${ }^{4}$ For more details on the Norwegian Natural Perils Pool, see https://www.naturskade.no/en/the-norwegian-naturalperils-pool/
} 
The results indicating that direct personal experience of a natural hazard might make people less concerned about climate change have some important implications for both future research and climate change policies. First, future research should focus on why people with direct personal experience of weather-related hazardous events in Norway might be less concerned about climate change and its consequences. One way would be to ask respondents questions about the type and severity of the damage they had experienced, their experience of emergency services and insurance companies, and their satisfaction with compensation, repairs, and reconstruction. Second, with regard to policy implications, Janković \& Schultz (2017) argue that the possible effects of anthropogenic climate change are often communicated to the public through arguments that anthropogenic climate change will produce more extreme weather. However, in their opinion, such attempts at invoking 'atmosfear' are not an effective means of either stimulating or legitimizing climate policies. Furthermore, the implications of our findings, as well as those of other studies (Zanocco 2018, Ogunbode 2019), suggest that referring to the possible direct and dramatic consequences of climate change may have a limited and at best a context-dependent effect in terms of increasing people's concerns about the personal risks and consequences of climate change.

Additionally, our results show that a considerable number of respondents reported that they had seen or experienced other more subtle and slower onset changes in the natural environment, which they attributed to climate change. The analysis revealed that the observed changes in the natural environment were related to increased concern about climate change and its consequences, as well as to increased likelihood of respondents being willing to take mitigation and adaption measures. Although these findings are of interest, the survey results do not allow for any firm conclusions about the causal directions: Do observed changes in the natural environment make people more concerned about climate change or are people likely to observe changes in the natural environment simply because they already are concerned about climate change? In a recent study Howe (2019) found that a person's prior belief about global climate change had an effect on his/her reported perceptions of changes in temperature and precipitation.

In order to ascertain the direction and strength of causality between observed changes in nature and perceptions of climate change and its consequences, future research should aim at collecting panel data in which respondents are followed over several years. This would enable the collection of baseline data on attitudes towards climate change, its consequences, mitigation, and adaptation efforts, as well as experience of hazards and observations of changes in the natural environment, which then could be followed over time and adjusted for new hazardous events that some participants might experience. Further, the reported changes in the natural environment could be compared to various measured changes in the natural environment.

The analysis also produced some interesting results with regard to individual characteristics and attitudes (the 'filter' in Figure 1). For age, the analysis revealed some tendency for older people being more concerned about climate change and more positive about mitigation and adaptation efforts than were members of the younger generations. The older being more concerned that the younger about the climate change contrasts the Lujala et al. (2015) study that found some evidence that older people tend to be less concerned about climate change and its consequences in Norway, a tendency also found for other Western countries (Poortinga et al. 2019). This may indicate that views among the older generations have changed over time, or that there is a curvilinear relation between the age and perceptions of the youngest and the 
oldest generations. For Norway, the Aasen (2017) study shows that the youngest (15-35-years old) and oldest generation (over 70 years) are most concerned about climate change. ${ }^{5}$

In line with the previous studies (e.g. Lujala et al.2015; Aasen 2017; Poortinga et al. 2019), we found that women tend to be more concerned about climate change than did men. Women were also more likely to have positive attitudes towards mitigation and more likely to have engaged with different types of mitigation efforts. However, with regard to willingness to adapt (i.e. whether the respondents had taken any measures to reduce the risks to their property resulting from weather-related natural hazards), gender did not play any role. One possible explanation for this result is that in Norwegian households men have more responsibility for property than do women and are thus more likely to adopt measures to safeguard their property.

Although previous studies have found higher education levels to be linked to higher degrees of concern about climate change and its consequences (e.g. Lujala et al. 2015; Aasen 2017; Poortinga et al. 2019), our analysis provided more nuanced results. Although respondents with higher levels of education were more likely to view climate change as a challenge for Norway, they were not more concerned about personal consequences compared with respondents with less education. Further, although we did not find a correlation between education level with attitudes towards mitigation, we did find that those with higher education levels were more likely to engage in concrete mitigation efforts than were those with less education. These results can suggest that persons with more education feel more confident that they will be able to cope with the personal consequences that climate change may cause them.

With regard to political leaning, our results support earlier results for Norway (Lujala et al. 2015; Aasen 2017; Krange et al. 2018) and for most other Western countries (Poortinga et al. 2019): persons who vote for right-wing parties tend to be less concerned about climate change. However, when taking actual steps to protect personal property, political leaning no longer had an impact on our results. Instead, direct personal experience of a previous hazard, perceived exposure to hazard, and income level seemed to determine who took measures to protect property from weather-related hazards. Also, older people were more likely to have taken such measures. Thus, the willingness to adapt seemed to be driven by the need to adopt measures to protect property from an increased risk of being affected by a weather-related hazard), by lifeexperience, and by the ability to finance such measures.

\section{Conclusions}

By using a nationally representative survey of 1045 participants and multivariate logistic regressions, this study has examined to what extent Norwegians' attitudes to climate change are related to their personal experiences of extreme weather events and respondents' personal observations of climate-related changes in the natural environment. The results show that respondents who reported having observed changes in the natural environment were much more

\footnotetext{
${ }^{5}$ As a robustness check, we run all our estimations with age brackets (ten-year intervals starting from 18-years old and ending at 68-years and older. The inclusion of the age brackets did not have any practical impact on the coefficients of our variables of interest, although they did slightly improve the significance levels of Direct personal hazard experience in estimations on Personal consequences. We found some evidence for a curvilinear relationship in estimations on Challenge for Norway: the youngest (18-27-year olds) and older generations (over 48 years) were more concerned. Further, for mitigation, the results suggest that such a curvilinear relation may exist, but the coefficients for the youngest generation are not significant at the conventional levels. The above mentioned results are included in the Replication do-file (Author 2019) and can also be accessed from the authors upon request.
} 
likely to perceive climate change as a major challenge for Norway and to a greater extent believe also that climate change would have personal consequences for themselves. These respondents were also more likely to have positive attitudes towards climate change mitigation and adaption efforts. Interestingly, those who had personal experience of a natural hazard reported lower levels of concern about climate change with respect to viewing climate change as a collective and personal challenge. However, they were more likely to report that they had undertaken measures to protect their homes from potential damage caused by future hazardous events. There is weak evidence that those who knew someone who had experienced damage as a result of a hazardous event might have been more concerned about climate change and have had more positive attitudes towards climate change mitigation and adaptation.

\section{References}

Author (2019). Replication data: The role of personal experiences in Norwegian perceptions of climate change. Mendeley Data, DOI.

Aasen, M. 2017. The polarization of public concern about climate change in Norway. Climate Policy 17(2), 213-230, doi: 10.1080/14693062.2015.1094727

Aasen, M. \& Vatn, A. 2018. Public attitudes toward climate policies: The effect of institutional contexts and political values. Ecological Economics 146(April), 106-114. https://doi.org/10.1016/j.ecolecon.2017.10.008

Akerlof, K., Maibach, E. W., Fitzgerald, D., Cedeno, A.Y. \& Neuman, A. 2013. Do people 'personally experience' global warming, and if so how, and does it matter? Global Environmental Change 23(1), 81-91. http://dx.doi.org/10.1016/j.gloenvcha.2012.07.006

Boon, H.J. 2016. Perceptions of climate change risk in four disaster-impacted rural Australian towns. Regional Environmental Change 16(1), 137-149. doi:10.1007/s10113-0140744-3

Broomell, S.B., Budescu, D.V. \& Por, H.-H. 2015. Personal experience with climate change predicts intentions to act. Global Environmental Change 32, 67-73. http://dx.doi.org/10.1016/j.gloenvcha.2015.03.001

Capstick, S. \& Pidgeon, N. 2014. Public perception of cold weather events as evidence for and against climate change. Climatic Change 122(4), 695-708. doi:10.1007/s10584013-1003-1

Clayton, S., Devine-Wright, P., Stern, P.C., Whitmarsh, L., Carrico, A., Steg, L., Swim \& Bonnes, M. 2015. Psychological research and global climate change. Nature Climate Change 5(7), 640-646. doi:10.1038/nclimate2622

Demski, C., Capstick, S., Pidgeon, N., Sposato, R. G., \& Spence, A. 2017. Experience of extreme weather affects climate change mitigation and adaptation responses. Climatic Change, 140(2), 149-164. doi:10.1007/s10584-016-1837-4

Goebbert, K., Jenkins-Smith, H.C., Klockow, K., Nowlin, M.C. \& Silva, C.L. 2012. Weather, climate, and worldviews: The sources and consequences of public perceptions of changes in local weather patterns. Weather, Climate, and Society 4(2), 132-144. doi:10.1175/WCAS-D-11-00044.1

Hamilton, L.C. \& Keim, B.D. 2009. Regional variation in perceptions about climate change. International Journal of Climatology 29(15), 2348-2352.

Hamilton, L.C. \& Stampone, M.D. 2013. Blowin' in the wind: Short-term weather and belief in anthropogenic climate change. Weather, Climate, and Society 5(2), 112-119. doi:10.1175/WCAS-D-12-00048.1 
Hamilton, L.C., Colocousis, C.R. \& Duncan, C.M. 2010. Place effects on environmental views. Rural Sociology 75(2), 326-347. doi:10.1111/j.1549-0831.2010.00013.x

Howe, P.D. 2018. Perceptions of seasonal weather are linked to beliefs about global climate change: Evidence from Norway. Climatic Change 148(4), 467-480. doi:10.1007/s 10584-018-2210-6

Howe, P.D. \& Leiserowitz, A. 2013. Who remembers a hot summer or a cold winter? The asymmetric effect of beliefs about global warming on perceptions of local climate conditions in the U.S. Global Environmental Change 23(6), 1488-1500. http://dx.doi.org/10.1016/j.gloenvcha.2013.09.014

Howe, P.D., Markowitz, E.M., Lee, T.M., Ko, C.-Y. \& Leiserowitz, A. 2013. Global perceptions of local temperature change. Nature Climate Change 3(4), 352-356. doi:http://www.nature.com/nclimate/journal/v3/n4/abs/nclimate1768.html\#supplement ary-information

Janković, V. \& Schultz, D.M. 2017. Atmosfear: Communicating the effects of climate change on extreme weather. Weather, Climate, and Society 9(1), 27-37. doi:10.1175/wcas-d-160030.1

Krange, O., Kaltenborn, B.P. \& Hultman, M. 2018. Cool dudes in Norway: Climate change denial among conservative Norwegian men. Environmental Sociology 5(1), 1-11. doi:10.1080/23251042.2018.1488516.

Leiserowitz, A.A. 2005. American risk perceptions: Is climate change dangerous? Risk Analysis 25(6), 1433-1442.

Li, Y., Johnson, E.J. \& Zaval, L. 2011. Local warming: Daily temperature change influences belief in global warming. Psychological Science 22(4), 454-459. doi:10.1177/0956797611400913

Lujala, P., Lein, H. \& Rød, J.K. 2015. Climate change, natural hazards, and risk perception: The role of proximity and personal experience. Local Environment 20(4), 489-509. https://doi.org/10.1080/13549839.2014.887666

McCright, A.M., Dunlap, R.E. \& Xiao, C. 2014. The impacts of temperature anomalies and political orientation on perceived winter warming. Nature Climate Change 4(12), 1077-1081. doi:10.1038/nclimate2443

McDonald, R.I., Chai, H.Y. \& Newell, B.R. 2015. Personal experience and the 'psychological distance' of climate change: An integrative review. Journal of Environmental Psychology 44, 109-118. http://dx.doi.org/10.1016/j.jenvp.2015.10.003

Myers, T.A., Maibach, E.W., Roser-Renouf, C., Akerlof, K. \& Leiserowitz, A.A. 2013. The relationship between personal experience and belief in the reality of global warming. Nature Climate Change 3(4), 343-347.

Ogunbode, C.A., Demski, C., Capstick, S.B. \& Sposato, R.G. 2019. Attribution matters: Revisiting the link between extreme weather experience and climate change mitigation responses. Global Environmental Change 54, 31-39. https://doi.org/10.1016/j.gloenvcha.2018.11.005

Poortinga, W., Whitmarsh, L., Steg, L., Böhm, G. \& Fisher, S. 2019. Climate change perceptions and their individual-level determinants: A cross-European analysis. Global Environmental Change 55(March), 25-35. https://doi.org/10.1016/j.gloenvcha.2019.01.007

Ray, A., Hughes, L., Konisky, D.M. \& Kaylor, C. 2017. Extreme weather exposure and support for climate change adaptation. Global Environmental Change 46, 104-113. doi:10.1016/j.gloenvcha.2017.07.002

Ryghaug, M., Sørensen, K.H. \& Næss, R. 2011. Making sense of global warming: Norwegians appropriating knowledge of anthropogenic climate change. Public Understanding of Science 20(6), 778-795. https://doi.org/10.1177/0963662510362657 
Scannell, L. \& Gifford, R. 2013. Personally relevant climate change: The role of place attachment and local versus global message framing in engagement. Environment and Behavior 45(1), 60-85. https://doi:10.1177/0013916511421196

Spence, A., Poortinga, W. \& Pidgeon, N. 2012. The psychological distance of climate change. Risk Analysis 32(6), 957-972. https://doi:10.1111/j.1539-6924.2011.01695.x

TNS Gallup. 2015. TNS Gallups Klimabarometer 2015. http://www.tnsgallup.no/globalassets/fra-webnodes/ekspertiseomrader/politikk-ogsamfunn/klimabarometer/tns-gallups-klimabarometer-2015_presentasjon.pdf (accessed 14 December 2018).

Whitmarsh, L. 2008. Are flood victims more concerned about climate change than other people? The role of direct experience in risk perception and behavioural response. Journal of Risk Research 11(3), 351-374, doi: 10.1080/13669870701552235

Wiest, S.L., Raymond, L. \& Clawson, R.A. 2015. Framing, partisan predispositions, and public opinion on climate change. Global Environmental Change 31, 187-198. doi:10.1016/j.gloenvcha.2014.12.006

Zanocco, C., Boudet, H., Nilson, R., Satein, H., Whitley, H. \& Flora, J. 2018. Place, proximity, and perceived harm: Extreme weather events and views about climate change. Climatic Change 149(3), 349-365. doi:10.1007/s10584-018-2251-x

Zaval, L., Keenan, E.A., Johnson, E.J. \& Weber, E.U. 2014. How warm days increase belief in global warming. Nature Climate Change 4(2), 143-147. doi:10.1038/nclimate2093 


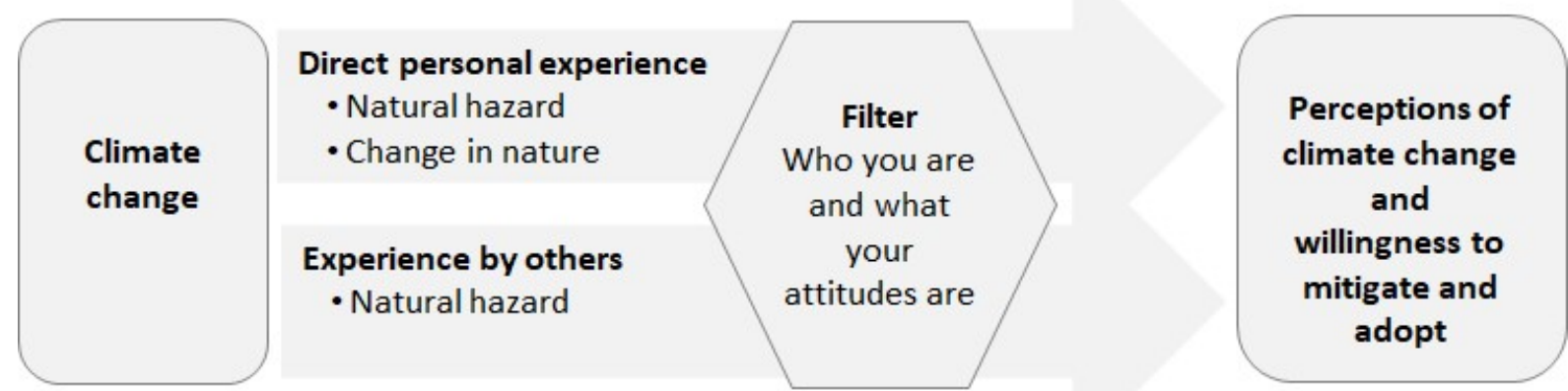

Fig. 1. A model of the relationships between climate-related experiences and perceptions of climate change (modified from Clayton et al. 2015, 642) 
Table 1. Summary of statistics for the variables included in the analysis and the questions on which the variables were based

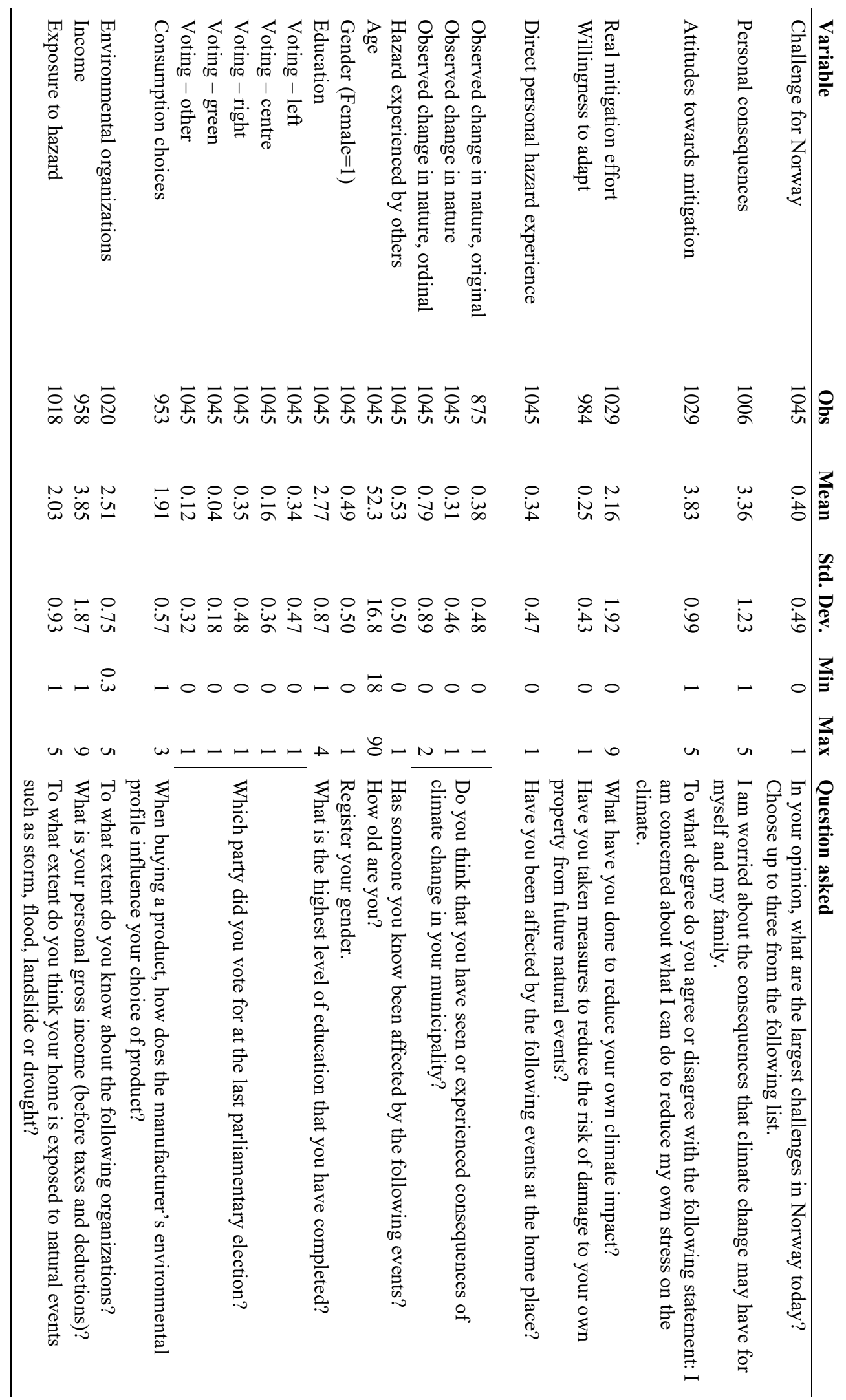


Table 2. Climate change as a national and personal challenge (odds ratio for logistic regression (Models 1-3) and ordered logistic regression (Models 4-6))

\begin{tabular}{|c|c|c|c|c|c|c|}
\hline & \multicolumn{3}{|c|}{ Challenge for Norway } & \multicolumn{3}{|c|}{ Personal consequences } \\
\hline & 1 & 2 & 3 & 4 & 5 & 6 \\
\hline Observed change in nature & $\begin{array}{c}2.86^{* * *} \\
(5.63)\end{array}$ & $\begin{array}{c}2.12^{* * *} \\
(3.43)\end{array}$ & $\begin{array}{c}2.74^{* * *} \\
(5.31)\end{array}$ & $\begin{array}{c}3.15^{* * *} \\
(6.70)\end{array}$ & $\begin{array}{c}2.43^{* * *} \\
(4.65)\end{array}$ & $\begin{array}{c}2.98^{* * *} \\
(6.29)\end{array}$ \\
\hline Direct personal hazard experience & $\begin{array}{l}0.64^{* *} \\
(-2.01)\end{array}$ & $\begin{array}{c}0.64^{*} \\
(-1.83)\end{array}$ & $\begin{array}{l}0.60 * * \\
(-2.30)\end{array}$ & $\begin{array}{c}0.77 \\
(-1.41)\end{array}$ & $\begin{array}{c}0.69^{*} \\
(-1.81)\end{array}$ & $\begin{array}{l}0.73^{*} \\
(-1.70)\end{array}$ \\
\hline Hazard experience by others & $\begin{array}{c}1.20 \\
(0.93)\end{array}$ & $\begin{array}{c}0.91 \\
(-0.42)\end{array}$ & $\begin{array}{c}1.10 \\
(0.48)\end{array}$ & $\begin{array}{l}1.35^{*} \\
\text { (1.76) }\end{array}$ & $\begin{array}{c}1.24 \\
(1.15)\end{array}$ & $\begin{array}{c}1.29 \\
(1.48)\end{array}$ \\
\hline Age & $\begin{array}{l}1.01^{* *} \\
(2.01)\end{array}$ & $\begin{array}{c}1.00 \\
(0.77)\end{array}$ & $\begin{array}{c}1.01 \\
(0.98)\end{array}$ & $\begin{array}{l}1.01 * * \\
(2.55)\end{array}$ & $\begin{array}{c}1.00 \\
(0.50)\end{array}$ & $\begin{array}{c}1.01 \\
(1.53)\end{array}$ \\
\hline Gender & $\begin{array}{l}1.40^{*} \\
(1.95)\end{array}$ & $\begin{array}{c}1.24 \\
(1.09)\end{array}$ & $\begin{array}{l}1.41^{* *} \\
(1.98)\end{array}$ & $\begin{array}{c}1.80 * * * \\
(3.93)\end{array}$ & $\begin{array}{c}1.74^{* * *} \\
(3.14)\end{array}$ & $\begin{array}{c}1.85^{* * *} \\
(4.03)\end{array}$ \\
\hline Education & $\begin{array}{c}1.41^{* * *} \\
(3.61)\end{array}$ & $\begin{array}{c}1.56^{* * *} \\
(3.97)\end{array}$ & $\begin{array}{c}1.34^{* * *} \\
(3.02)\end{array}$ & $\begin{array}{c}1.09 \\
(1.16)\end{array}$ & $\begin{array}{c}0.96 \\
(-0.47)\end{array}$ & $\begin{array}{c}1.01 \\
(0.18)\end{array}$ \\
\hline Voting green & $\begin{array}{c}4.86 * * * \\
(3.51)\end{array}$ & $\begin{array}{l}2.50^{*} \\
(1.65)\end{array}$ & & $\begin{array}{c}5.15^{* * *} \\
(4.26)\end{array}$ & $\begin{array}{c}4.23 * * * \\
(3.19)\end{array}$ & \\
\hline Voting left & $\begin{array}{c}2.60^{* * *} \\
(4.41)\end{array}$ & $\begin{array}{l}1.84^{* *} \\
(2.53)\end{array}$ & & $\begin{array}{c}2.53^{* * *} \\
(5.61)\end{array}$ & $\begin{array}{c}2.06 * * * \\
(4.01)\end{array}$ & \\
\hline Voting centre & $\begin{array}{c}2.35^{* * *} \\
(3.33)\end{array}$ & $\begin{array}{c}1.41 \\
(1.16)\end{array}$ & & $\begin{array}{l}1.74 * * \\
(2.53)\end{array}$ & $\begin{array}{c}1.28 \\
(1.01)\end{array}$ & \\
\hline Voting other & $\begin{array}{l}1.76^{*} \\
(1.87)\end{array}$ & $\begin{array}{c}1.71 \\
(1.50)\end{array}$ & & $\begin{array}{c}2.63^{* * *} \\
(3.09)\end{array}$ & $\begin{array}{c}2.07 \\
(1.63)\end{array}$ & \\
\hline Voting right & & & $\begin{array}{c}0.45^{* * *} \\
(-3.98)\end{array}$ & & & $\begin{array}{c}0.44 * * * \\
(-5.17)\end{array}$ \\
\hline Consumption choices & & $\begin{array}{c}2.59 * * * \\
(4.91)\end{array}$ & & & $\begin{array}{c}2.24^{* * *} \\
(4.52)\end{array}$ & \\
\hline Environmental organizations & & $\begin{array}{l}1.37^{* *} \\
(2.43)\end{array}$ & $\begin{array}{c}1.59 * * * \\
(4.12)\end{array}$ & & $\begin{array}{c}1.37^{* *} \\
(2.46)\end{array}$ & $\begin{array}{c}1.52^{* * *} \\
(3.69)\end{array}$ \\
\hline Income & & $\begin{array}{c}0.93 \\
(-1.11)\end{array}$ & & & $\begin{array}{l}1.09^{*} \\
(1.75)\end{array}$ & \\
\hline Exposure to hazard & & $\begin{array}{c}1.00 \\
(-0.018)\end{array}$ & & & $\begin{array}{c}1.07 \\
(0.69)\end{array}$ & \\
\hline Number of observations & 1045 & 861 & 1020 & 1006 & 845 & 992 \\
\hline
\end{tabular}

Notes: Robust $t$-values in parentheses. All model specifications include county fixed effects. ${ }^{*} p<0.1,{ }^{* *} p<$ $0.05, * * * 00.01$ 
Table 3. Attitudes towards climate change mitigation and mitigation efforts (odds ratio for ordered logistic regression)

\begin{tabular}{|c|c|c|c|c|c|c|}
\hline & \multicolumn{3}{|c|}{ Attitudes towards mitigation } & \multicolumn{3}{|c|}{ Real mitigation effort } \\
\hline & 1 & 2 & 3 & 4 & 5 & 6 \\
\hline \multirow[t]{2}{*}{ Observed change in nature } & $2.11 * * *$ & $1.76^{* * *}$ & $2.04 * * *$ & $2.08 * * *$ & $1.72 * * *$ & $1.91 * * *$ \\
\hline & $(4.27)$ & $(2.73)$ & $(4.01)$ & $(4.53)$ & $(2.81)$ & $(3.87)$ \\
\hline \multirow[t]{2}{*}{ Direct personal hazard experience } & 1.13 & 0.79 & 0.97 & 1.13 & 0.79 & 1.01 \\
\hline & $(0.64)$ & $(-1.12)$ & $(-0.17)$ & $(0.63)$ & $(-1.10)$ & $(0.044)$ \\
\hline \multirow[t]{2}{*}{ Hazard experience by others } & 1.26 & 1.16 & 1.26 & 1.24 & 1.20 & 1.22 \\
\hline & $(1.36)$ & $(0.75)$ & $(1.34)$ & (1.29) & $(0.97)$ & $(1.13)$ \\
\hline \multirow[t]{2}{*}{ Age } & $1.02 * * *$ & $1.01 * *$ & $1.01 * * *$ & 1.01 & 1.00 & 1.00 \\
\hline & $(4.23)$ & $(2.24)$ & $(2.61)$ & $(1.43)$ & $(-0.50)$ & $(0.049)$ \\
\hline \multirow[t]{2}{*}{ Gender } & $2.42 * * *$ & $2.06 * * *$ & $2.47 * * *$ & $2.25^{* * *}$ & $2.08 * * *$ & $2.33 * * *$ \\
\hline & $(5.64)$ & (3.82) & $(5.69)$ & $(5.29)$ & (3.91) & $(5.49)$ \\
\hline \multirow[t]{2}{*}{ Education } & 1.08 & 1.03 & 1.02 & $1.29 * * *$ & $1.37 * * *$ & $1.24 * * *$ \\
\hline & $(0.90)$ & $(0.32)$ & $(0.22)$ & $(3.20)$ & (3.39) & $(2.77)$ \\
\hline \multirow[t]{2}{*}{ Voting green } & $11.8^{* * *}$ & $3.29 * *$ & & $5.27 * * *$ & $2.19 *$ & \\
\hline & $(5.05)$ & $(2.31)$ & & $(5.07)$ & $(1.77)$ & \\
\hline \multirow[t]{2}{*}{ Voting left } & $1.90 * * *$ & $1.46^{*}$ & & $2.09 * * *$ & $1.54 * *$ & \\
\hline & $(3.42)$ & (1.78) & & $(4.22)$ & $(2.33)$ & \\
\hline \multirow[t]{2}{*}{ Voting centre } & $1.81^{* *}$ & 1.05 & & $2.33 * * *$ & 1.37 & \\
\hline & $(2.46)$ & $(0.18)$ & & (3.79) & $(1.22)$ & \\
\hline \multirow[t]{2}{*}{ Voting other } & $2.16 * * *$ & 1.51 & & 1.52 & 1.40 & \\
\hline & $(2.93)$ & (1.14) & & (1.61) & $(1.01)$ & \\
\hline \multirow[t]{2}{*}{ Voting right } & & & $0.53 * * *$ & & & $0.50 * * *$ \\
\hline & & & $(-3.76)$ & & & $(-4.42)$ \\
\hline \multirow[t]{2}{*}{ Consumption choices } & & $5.62 * * *$ & & & $4.39 * * *$ & \\
\hline & & $(9.70)$ & & & $(9.00)$ & \\
\hline \multirow[t]{2}{*}{ Environmental organizations } & & $1.27^{*}$ & $1.59 * * *$ & & $1.41 * * *$ & $1.74 * * *$ \\
\hline & & $(1.84)$ & (3.96) & & $(2.62)$ & $(4.94)$ \\
\hline \multirow[t]{2}{*}{ Income } & & 1.01 & & & 0.94 & \\
\hline & & $(0.24)$ & & & $(-1.17)$ & \\
\hline \multirow[t]{2}{*}{ Exposure to hazard } & & 1.13 & & & 1.09 & \\
\hline & & $(1.21)$ & & & $(0.91)$ & \\
\hline Number of observations & 1029 & 860 & 1014 & 1029 & 860 & 1014 \\
\hline
\end{tabular}


Table 4. Willingness to adapt (odds ratio for logistic regression)

\begin{tabular}{|c|c|c|c|c|c|c|}
\hline & 1 & 2 & 3 & 4 & 5 & 6 \\
\hline \multirow[t]{2}{*}{ Observed change in nature } & $1.73^{* *}$ & 1.31 & $1.53^{*}$ & 1.54 & 1.15 & 1.33 \\
\hline & $(2.53)$ & $(1.11)$ & $(1.94)$ & $(1.57)$ & $(0.46)$ & $(1.02)$ \\
\hline \multirow[t]{2}{*}{ Direct personal hazard experience } & $2.82 * * *$ & $2.61 * * *$ & $2.39 * * *$ & $4.07^{* * *}$ & $3.07^{* * *}$ & $3.35 * * *$ \\
\hline & $(4.18)$ & (3.18) & $(3.21)$ & $(4.11)$ & $(2.73)$ & $(3.46)$ \\
\hline \multirow[t]{2}{*}{ Hazard experience by others } & 1.37 & 1.21 & 1.35 & 1.17 & 1.08 & 1.26 \\
\hline & $(1.29)$ & $(0.67)$ & $(1.22)$ & $(0.47)$ & $(0.22)$ & $(0.72)$ \\
\hline \multirow[t]{2}{*}{ Age } & $1.03 * * *$ & $1.02 * * *$ & $1.03^{* * *}$ & $1.02^{* *}$ & 1.01 & $1.02^{* *}$ \\
\hline & $(3.78)$ & $(3.29)$ & $(4.16)$ & $(2.31)$ & $(1.04)$ & $(2.06)$ \\
\hline \multirow[t]{2}{*}{ Gender } & 0.86 & 1.01 & 1.00 & 1.05 & 0.99 & 1.21 \\
\hline & $(-0.76)$ & $(0.064)$ & $(0.0046)$ & $(0.18)$ & $(-0.026)$ & $(0.75)$ \\
\hline \multirow[t]{2}{*}{ Education } & 1.01 & $0.78^{*}$ & 1.04 & 1.02 & 0.92 & 1.08 \\
\hline & $(0.13)$ & $(-1.82)$ & $(0.36)$ & $(0.17)$ & $(-0.48)$ & $(0.58)$ \\
\hline \multirow[t]{2}{*}{ Voting green } & 1.24 & 0.71 & & 1.42 & 0.94 & \\
\hline & $(0.38)$ & $(-0.57)$ & & $(0.44)$ & $(-0.079)$ & \\
\hline \multirow[t]{2}{*}{ Voting left } & 0.81 & 0.95 & & 0.74 & 0.75 & \\
\hline & $(-0.93)$ & $(-0.20)$ & & $(-1.05)$ & $(-0.85)$ & \\
\hline \multirow[t]{2}{*}{ Voting centre } & 1.15 & 1.35 & & 1.32 & 1.51 & \\
\hline & $(0.50)$ & $(0.92)$ & & $(0.72)$ & $(1.01)$ & \\
\hline \multirow[t]{2}{*}{ Voting other } & 0.56 & $0.33^{* *}$ & & $0.39 *$ & $0.21^{*}$ & \\
\hline & $(-1.33)$ & $(-2.24)$ & & $(-1.67)$ & $(-1.96)$ & \\
\hline \multirow[t]{2}{*}{ Voting right } & & & 1.27 & & & 1.31 \\
\hline & & & (1.17) & & & $(1.04)$ \\
\hline \multirow[t]{2}{*}{ Consumption choices } & & $2.21^{* * *}$ & & & $2.45^{* * *}$ & \\
\hline & & (3.69) & & & $(3.08)$ & \\
\hline \multirow[t]{2}{*}{ Environmental organizations } & & 1.09 & 1.16 & & 0.81 & 0.97 \\
\hline & & $(0.47)$ & (0.93) & & $(-0.83)$ & $(-0.15)$ \\
\hline \multirow[t]{2}{*}{ Income } & & $1.20 * * *$ & & & 1.03 & \\
\hline & & $(2.59)$ & & & $(0.32)$ & \\
\hline \multirow[t]{2}{*}{ Exposure to hazard } & & $1.26^{*}$ & $1.30^{* *}$ & & 1.32 & 1.20 \\
\hline & & $(1.80)$ & $(2.23)$ & & $(1.52)$ & (1.14) \\
\hline Number of observations & 984 & 828 & 953 & 527 & 447 & 514 \\
\hline
\end{tabular}

Notes: Robust $t$-values in parentheses. All model specifications include county fixed effects. ${ }^{*} p<0.1,{ }^{* *} p<$ $0.05,{ }^{* * *} p<0.01$ 
Appendix 1. Climate change as a national and personal challenge, alternative coding for Observed change in nature

\begin{tabular}{|c|c|c|c|c|c|c|c|c|c|c|c|c|}
\hline & \multicolumn{3}{|c|}{ Challenge for Norway } & \multicolumn{3}{|c|}{ Personal consequences } & \multicolumn{3}{|c|}{ Challenge for Norway } & \multicolumn{3}{|c|}{ Personal consequences } \\
\hline & 1 & 2 & 3 & 4 & 5 & 6 & 7 & 8 & 9 & 10 & 11 & 12 \\
\hline Observed change in nature, original & $\begin{array}{c}3.07^{* * *} \\
(5.67)\end{array}$ & $\begin{array}{c}2.25^{* * *} \\
(3.35)\end{array}$ & $\begin{array}{c}2.93^{* * *} \\
(5.35)\end{array}$ & $\begin{array}{c}3.71^{* * *} \\
(7.18)\end{array}$ & $\begin{array}{c}2.89 * * * \\
(5.22)\end{array}$ & $\begin{array}{c}3.48^{* * *} \\
(6.73)\end{array}$ & & & & & & \\
\hline Observed change in nature, ordinal & & & & & & & $\begin{array}{c}1.74^{* * *} \\
(5.64)\end{array}$ & $\begin{array}{c}1.53^{* * *} \\
(3.60)\end{array}$ & $\begin{array}{c}1.71 * * * \\
(5.37)\end{array}$ & $\begin{array}{c}1.89 * * * \\
(7.12)\end{array}$ & $\begin{array}{c}1.68^{* * *} \\
(5.20)\end{array}$ & $\begin{array}{c}1.86^{* * *} \\
(6.78)\end{array}$ \\
\hline Direct personal hazard experience & $\begin{array}{l}0.58^{* *} \\
(-2.22)\end{array}$ & $\begin{array}{l}0.52^{* *} \\
(-2.44)\end{array}$ & $\begin{array}{l}0.56 * * \\
(-2.40)\end{array}$ & $\begin{array}{c}0.75 \\
(-1.41)\end{array}$ & $\begin{array}{c}0.65 * \\
(-1.90)\end{array}$ & $\begin{array}{c}0.69 * \\
(-1.80)\end{array}$ & $\begin{array}{l}0.62^{* *} \\
(-2.18)\end{array}$ & $\begin{array}{c}0.63^{*} \\
(-1.91)\end{array}$ & $\begin{array}{l}0.58^{* *} \\
(-2.46)\end{array}$ & $\begin{array}{c}0.71^{*} \\
(-1.79)\end{array}$ & $\begin{array}{l}0.66 * * \\
(-2.04)\end{array}$ & $\begin{array}{l}0.68 * * \\
(-2.06)\end{array}$ \\
\hline Hazard experience by others & $\begin{array}{c}1.20 \\
(0.82)\end{array}$ & $\begin{array}{c}0.95 \\
(-0.20)\end{array}$ & $\begin{array}{c}1.08 \\
(0.33)\end{array}$ & $\begin{array}{c}1.27 \\
(1.30)\end{array}$ & $\begin{array}{c}1.07 \\
(0.35)\end{array}$ & $\begin{array}{c}1.22 \\
(1.06)\end{array}$ & $\begin{array}{c}1.19 \\
(0.86)\end{array}$ & $\begin{array}{c}0.89 \\
(-0.52)\end{array}$ & $\begin{array}{c}1.08 \\
(0.38)\end{array}$ & $\begin{array}{c}1.33 \\
(1.64)\end{array}$ & $\begin{array}{c}1.20 \\
(0.97)\end{array}$ & $\begin{array}{c}1.26 \\
(1.33)\end{array}$ \\
\hline Age & $\begin{array}{c}1.01 \\
(0.99)\end{array}$ & $\begin{array}{c}1.00 \\
(-0.40)\end{array}$ & $\begin{array}{c}1.00 \\
(0.081)\end{array}$ & $\begin{array}{c}1.01^{* * *} \\
(2.62)\end{array}$ & $\begin{array}{c}1.00 \\
(0.60)\end{array}$ & $\begin{array}{c}1.01 \\
(1.53)\end{array}$ & $\begin{array}{l}1.01^{*} \\
(1.88)\end{array}$ & $\begin{array}{c}1.00 \\
(0.70)\end{array}$ & $\begin{array}{c}1.00 \\
(0.88)\end{array}$ & $\begin{array}{l}1.01^{* *} \\
(2.35)\end{array}$ & $\begin{array}{l}1.00 \\
(0.43)\end{array}$ & $\begin{array}{c}1.01 \\
(1.39)\end{array}$ \\
\hline Gender & $\begin{array}{l}1.47^{* *} \\
(2.01)\end{array}$ & $\begin{array}{c}1.33 \\
(1.30)\end{array}$ & $\begin{array}{l}1.48^{* *} \\
(2.04)\end{array}$ & $\begin{array}{c}1.83^{* * *} \\
(3.66)\end{array}$ & $\begin{array}{l}1.61^{* *} \\
(2.45)\end{array}$ & $\begin{array}{c}1.89 * * * \\
(3.80)\end{array}$ & $\begin{array}{l}1.35 * \\
(1.75)\end{array}$ & $\begin{array}{c}1.22 \\
(0.98)\end{array}$ & $\begin{array}{l}1.36 * \\
(1.77)\end{array}$ & $\begin{array}{c}1.76^{* * *} \\
(3.78)\end{array}$ & $\begin{array}{c}1.71 * * * \\
(3.07)\end{array}$ & $\begin{array}{c}1.80^{* * * *} \\
(3.89)\end{array}$ \\
\hline Education & $\begin{array}{c}1.39 * * * \\
(3.11)\end{array}$ & $\begin{array}{c}1.48^{* * *} \\
(3.16)\end{array}$ & $\begin{array}{c}1.33^{* * *} \\
(2.69)\end{array}$ & $\begin{array}{c}1.12 \\
(1.37)\end{array}$ & $\begin{array}{c}0.97 \\
(-0.34)\end{array}$ & $\begin{array}{c}1.03 \\
(0.31)\end{array}$ & $\begin{array}{c}1.40 * * * \\
(3.55)\end{array}$ & $\begin{array}{c}1.56 * * * \\
(3.93)\end{array}$ & $\begin{array}{c}1.33^{* * *} \\
(2.97)\end{array}$ & $\begin{array}{c}1.08 \\
(1.00)\end{array}$ & $\begin{array}{c}0.96 \\
(-0.49)\end{array}$ & $\begin{array}{c}1.00 \\
(0.052)\end{array}$ \\
\hline Voting green & $\begin{array}{c}4.30 * * * \\
(3.06)\end{array}$ & $\begin{array}{c}2.02 \\
(1.17)\end{array}$ & & $\begin{array}{c}5.06 * * * \\
(3.95)\end{array}$ & $\begin{array}{c}3.64 * * * \\
(2.67)\end{array}$ & & $\begin{array}{c}4.76 * * * \\
(3.46)\end{array}$ & $\begin{array}{c}2.46 \\
(1.62)\end{array}$ & & $\begin{array}{c}4.88 * * * \\
(4.05)\end{array}$ & $\begin{array}{c}4.03 * * * \\
(3.07)\end{array}$ & \\
\hline Voting left & $\begin{array}{c}2.58 * * * \\
(4.03)\end{array}$ & $\begin{array}{l}1.82^{* *} \\
(2.30)\end{array}$ & & $\begin{array}{c}2.42^{* * *} \\
(5.01)\end{array}$ & $\begin{array}{c}1.94 * * * \\
(3.46)\end{array}$ & & $\begin{array}{c}2.56 * * * \\
(4.35)\end{array}$ & $\begin{array}{l}1.82^{* *} \\
(2.48)\end{array}$ & & $\begin{array}{c}2.47^{* * *} \\
(5.42)\end{array}$ & $\begin{array}{c}2.01 * * * \\
(3.87)\end{array}$ & \\
\hline Voting centre & $\begin{array}{c}2.44^{* * *} \\
(3.17)\end{array}$ & $\begin{array}{c}1.57 \\
(1.38)\end{array}$ & & $\begin{array}{l}1.53^{*} \\
(1.80)\end{array}$ & $\begin{array}{c}1.13 \\
(0.47)\end{array}$ & & $\begin{array}{c}2.31^{* * *} \\
(3.24)\end{array}$ & $\begin{array}{c}1.38 \\
(1.08)\end{array}$ & & $\begin{array}{l}1.69 * * \\
(2.42)\end{array}$ & $\begin{array}{c}1.24 \\
(0.89)\end{array}$ & \\
\hline Voting other & $\begin{array}{c}1.48 \\
(1.14)\end{array}$ & $\begin{array}{c}1.29 \\
(0.59)\end{array}$ & & $\begin{array}{c}3.00^{* * *} \\
(2.94)\end{array}$ & $\begin{array}{l}3.04^{* *} \\
(2.04)\end{array}$ & & $\begin{array}{c}1.59 \\
(1.55)\end{array}$ & $\begin{array}{c}1.62 \\
(1.34)\end{array}$ & & $\begin{array}{c}2.36 * * * \\
(2.73)\end{array}$ & $\begin{array}{c}1.91 \\
(1.41)\end{array}$ & \\
\hline Voting right & & & $\begin{array}{c}0.46^{* * *} \\
(-3.54)\end{array}$ & & & $\begin{array}{c}0.46^{* * *} \\
(-4.58)\end{array}$ & & & $\begin{array}{c}0.46^{* * * *} \\
(-3.84)\end{array}$ & & & $\begin{array}{c}0.46 * * * \\
(-4.89)\end{array}$ \\
\hline Consumption choices & & $\begin{array}{c}2.96 * * * \\
(5.11)\end{array}$ & & & $\begin{array}{c}2.35^{* * *} \\
(4.70)\end{array}$ & & & $\begin{array}{c}2.53 * * * \\
(4.78)\end{array}$ & & & $\begin{array}{c}2.21 * * * \\
(4.43)\end{array}$ & \\
\hline Environmental organizations & & $\begin{array}{l}1.30 * \\
(1.94)\end{array}$ & $\begin{array}{c}1.60 * * * \\
(3.89)\end{array}$ & & $\begin{array}{c}1.39 * * \\
(2.43)\end{array}$ & $\begin{array}{c}1.55^{* * *} \\
(3.51)\end{array}$ & & $\begin{array}{l}1.37^{* *} \\
(2.46)\end{array}$ & $\begin{array}{c}1.60^{* * *} \\
(4.12)\end{array}$ & & $\begin{array}{c}1.37^{* *} \\
(2.46)\end{array}$ & $\begin{array}{c}1.53^{* * * *} \\
(3.73)\end{array}$ \\
\hline Income & & $\begin{array}{c}0.95 \\
(-0.74)\end{array}$ & & & $\begin{array}{c}1.07 \\
(1.27)\end{array}$ & & & $\begin{array}{c}0.93 \\
(-1.14)\end{array}$ & & & $\begin{array}{c}1.08 \\
(1.63)\end{array}$ & \\
\hline Exposure to hazard & & $\begin{array}{c}1.00 \\
(-0.014)\end{array}$ & & & $\begin{array}{c}1.09 \\
(0.81)\end{array}$ & & & $\begin{array}{c}0.98 \\
(-0.15)\end{array}$ & & & $\begin{array}{c}1.06 \\
(0.55)\end{array}$ & \\
\hline Number of observations & 875 & 741 & 860 & 852 & 728 & 840 & 1045 & 861 & 1020 & 1006 & 845 & 992 \\
\hline
\end{tabular}


Appendix 2. Mitigation efforts, robustness checks

\begin{tabular}{|c|c|c|c|c|c|c|}
\hline & 1 & 2 & 3 & 4 & 5 & 6 \\
\hline \multirow[t]{2}{*}{ Observed change in nature } & $1.41^{* * *}$ & $1.27^{* * *}$ & $1.37^{* * *}$ & $1.77^{* * *}$ & $1.75^{* *}$ & $1.79 * * *$ \\
\hline & $(4.53)$ & (3.05) & $(4.11)$ & $(3.19)$ & $(2.58)$ & $(3.17)$ \\
\hline \multirow{2}{*}{ Direct personal hazard experience } & 1.06 & 0.95 & 1.02 & 1.07 & 0.86 & 1.11 \\
\hline & $(0.63)$ & $(-0.56)$ & $(0.17)$ & $(0.30)$ & $(-0.54)$ & $(0.42)$ \\
\hline \multirow[t]{2}{*}{ Hazard experience by others } & 1.13 & 1.06 & 1.10 & 0.97 & 0.89 & 0.93 \\
\hline & $(1.36)$ & $(0.63)$ & $(1.06)$ & $(-0.16)$ & $(-0.55)$ & $(-0.35)$ \\
\hline \multirow[t]{2}{*}{ Age } & 1.00 & 1.00 & 1.00 & $0.99 * *$ & $0.98 * * *$ & $0.98^{* * *}$ \\
\hline & $(1.01)$ & $(-0.088)$ & $(-0.20)$ & $(-2.25)$ & $(-2.82)$ & $(-2.91)$ \\
\hline \multirow[t]{2}{*}{ Gender } & $1.46 * * *$ & $1.33^{* * *}$ & $1.45^{* * *}$ & 1.31 & 1.35 & $1.36^{*}$ \\
\hline & $(4.95)$ & $(3.46)$ & (4.99) & $(1.51)$ & $(1.36)$ & $(1.69)$ \\
\hline \multirow[t]{2}{*}{ Education } & $1.13^{* * *}$ & $1.15^{* * *}$ & $1.11^{* * *}$ & $1.23 * *$ & $1.32 * *$ & $1.25^{* *}$ \\
\hline & $(3.28)$ & $(3.37)$ & $(2.83)$ & $(2.30)$ & $(2.51)$ & $(2.38)$ \\
\hline \multirow[t]{2}{*}{ Voting green } & $2.00 * * *$ & 1.21 & & $3.16 * * *$ & 1.72 & \\
\hline & $(6.18)$ & (1.39) & & $(3.02)$ & $(1.16)$ & \\
\hline \multirow[t]{2}{*}{ Voting left } & $1.52 * * *$ & $1.28 * * *$ & & $1.53^{* *}$ & 1.19 & \\
\hline & $(4.58)$ & $(2.68)$ & & $(2.23)$ & $(0.77)$ & \\
\hline \multirow[t]{2}{*}{ Voting centre } & $1.58 * * *$ & $1.21 *$ & & $2.14 * * *$ & 1.43 & \\
\hline & $(4.26)$ & $(1.75)$ & & (3.17) & $(1.34)$ & \\
\hline \multirow[t]{2}{*}{ Voting other } & $1.28 *$ & 1.18 & & 0.79 & 0.98 & \\
\hline & $(1.75)$ & $(1.03)$ & & $(-0.66)$ & $(-0.041)$ & \\
\hline \multirow[t]{2}{*}{ Voting right } & & & $0.69 * * *$ & & & $0.69 * *$ \\
\hline & & & $(-4.39)$ & & & $(-2.19)$ \\
\hline \multirow[t]{2}{*}{ Consumption choices } & & $1.90 * * *$ & & & $3.11^{* * *}$ & \\
\hline & & $(9.01)$ & & & $(5.55)$ & \\
\hline \multirow[t]{2}{*}{ Environmental organizations } & & $1.14^{* *}$ & $1.27 * * *$ & & 1.18 & $1.48^{* * *}$ \\
\hline & & $(2.27)$ & $(4.52)$ & & $(1.08)$ & $(2.90)$ \\
\hline \multirow[t]{2}{*}{ Income } & & 0.96 & & & 0.93 & \\
\hline & & $(-1.52)$ & & & $(-1.30)$ & \\
\hline \multirow[t]{2}{*}{ Exposure to hazard } & & 1.05 & & & 1.03 & \\
\hline & & $(1.00)$ & & & $(0.28)$ & \\
\hline Number of observations & 1029 & 860 & 1014 & 744 & 621 & 734 \\
\hline
\end{tabular}

Notes: Table shows the odds ratio for negative binomial regression (Models 1-3; dependent variable Real mitigation effort) and ordered logistic regression (Models 4-6; dependent variable Real mitigation effort with alternative coding). Robust $t$-values in parentheses. All model specifications include county fixed effects. ${ }^{*} p<0.1, * * p<0.05,{ }^{* * *} p<0.01$ 